De betekenis van levensverhalen 


\section{De betekenis van levensverhalen}

Theoretische beschouwingen en toepassingen in onderzoek en praktijk

Ernst Bohlmeijer, Lausanne Mies en Gerben Westerhof

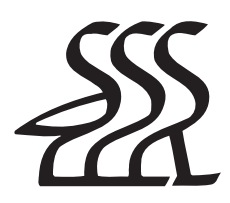

Bohn Stafleu van Loghum

Houten 2007 
(C) Bohn Stafleu van Loghum, 2007

Alle rechten voorbehouden. Niets uit deze uitgave mag worden verveelvoudigd, opgeslagen in een geautomatiseerd gegevensbestand, of openbaar gemaakt, in enige vorm of op enige wijze, hetzij elektronisch, mechanisch, door fotokopieën of opnamen, hetzij op enige andere manier, zonder voorafgaande schriftelijke toestemming van de uitgever.

Voor zover het maken van kopieën uit deze uitgave is toegestaan op grond van artikel I6b Auteurswet I9I2 $j^{\circ}$ het Besluit van 20 juni I974, Stb. 35I, zoals gewijzigd bij Besluit van 23 augustus I985, Stb. 47I en artikel I7 Auteurswet I9I2, dient men de daarvoor wettelijk verschuldigde vergoedingen te voldoen aan de Stichting Reprorecht (Postbus 305I, 2I30 KB Hoofddorp). Voor het overnemen van (een) gedeelte(n) uit deze uitgave in bloemlezingen, readers en andere compilatiewerken (artikel I6 Auteurswet I9I2) dient men zich tot de uitgever te wenden.

Samensteller(s) en uitgever zijn zich volledig bewust van hun taak een betrouwbare uitgave te verzorgen. Niettemin kunnen zij geen aansprakelijkheid aanvaarden voor drukfouten en andere onjuistheden die eventueel in deze uitgave voorkomen.

ISBN 9789031348749

NUR 775

Ontwerp omslag: Studio Bassa, Culemborg

Ontwerp binnenwerk: Studio Bassa, Culemborg

Automatische opmaak: Alfabase, Alphen aan den Rijn

Dit boek is tot stand gekomen dankzij een subsidie van ZonMw

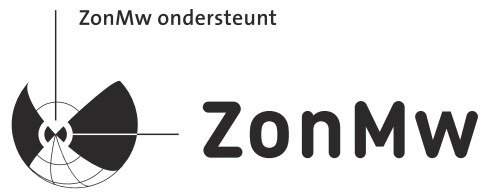

Illustratieverantwoording hoofdstuk 2

Figuur 2.2

Kabakov, I. (1995). The rope of life and other installations. Frankfurt am Main: Verlag Museum für Moderne Kunst (bezit MMK Frankfurt am Main).

Figuur 2.3

Chew, S.C. (1962). The pelgrimage of life. New Haven/London: Yale University Press.

Figuur 2.4

Schleinitz, O. von (1902). Walter Crane. Bielefeld/Leipzig: Verlag von Velhagen \& Klasing.

Figuur 2.5

Hazelzet, K. (s.a.). De levenstrap. Zwolle: Catena.

Hazelzet, K. (s.a.). Het leven in weinig woorden. Westfriese tradities rond de levenstrap. Hoorn: Westfries Museum (bezit Rijksprentenkabinet Amsterdam).

Bohn Stafleu van Loghum

Het Spoor 2

Postbus 246

3990 GA Houten

www.bsl.nl
Distributeur in België:

Standaard Uitgeverij

Mechelsesteenweg 203

20I8 Antwerpen

www.standaarduitgeverij.be 


\section{Inhoud}

Introductie

II

Ernst Bohlmeijer, Lausanne Mies en Gerben Westerhof

Proloog: De waarheid van de onwaarheid

Marcel Möring

Deel I Theoretische beschouwingen

I

Herinneringen, levensverhalen en gezondheid

29

Ernst Bohlmeijer

2

Het levensverhaal als constructie

4I

Gerard M. Brugman

3 De wereld als verhaal: Naar een narratief perspectief op

ouder worden, identiteit, en het leven van alledag

William L. Randall

Intermezzo: Feiten en waarheid binnen de context van

levensverhalen

83

Ernst Bohlmeijer

$4 \quad$ Tegen de tijdstroom in: Het autobiografisch geheugen 85

Ineke Wessel

Levensverhaal, troost en geestelijke zorg bij mensen met kanker

Johan Bouwer

Intermezzo: Levensverhalen in het museum

109

Herman de Boer 
$6 \quad$ Als wijn bij de maaltijd: (Levens)verhalen in de joodse traditie

Marcus van Loopik

$7 \quad$ Mijn cultuur, mijn identiteit: Politieke, ideologische en affectieve aspecten van levensverhalen

Angela Roothaan

Intermezzo: Literatuur of geschiedenis? Bestsellers zijn het

Gerben Westerhof

8 Levensverhalen als data in sociologisch onderzoek Gerhard Nijhof

9 Tijd en identiteit: De opkomst van de autobiografie in de lange negentiende eeuw

Arianne Baggerman

Intermezzo: 'Van het leven - mijn leven - een verhaal maken en het daarmee draaglijk maken': Hoe Adriaan van Dis inzicht verwerft door autobiografie Gerben Westerhof

Io Gesproken en geschreven levensverhalen: Op zoek naar een 'antropologie van het overleven' via oral history

Selma Leydesdorff

II Levensverhalen van daklozen: Creativiteit, interactie en macht in het onderzoeksproces

Geeske Hoogenboezem

Verhalen in de antropologie: Wat Zuid-Afrikaanse ouderen en antropologen doen met levensverhalen Els van Dongen 
Intermezzo: Roze Reminiscentie - Het feest der Herkenning en Erkenning 203

Ietje de Groot

I3 Dilthey en Gadamer: Twee opvattingen over het interpreteren van levensverhalen

Hans-Jan Kuipers

I4 De 'stille' generatie aan het woord

Karen van Kordelaar en Gerben Westerhof

Intermezzo: Gewoon als ieder ander: levensverhalen van jongeren met chronische aandoeningen

Anneloes van Staa

I5 Hoe Marokkaanse ouderen zoeken naar gezond leven in Nederland

Anneke Sools

I6 Het verhaal als remedie: Onderzoek naar de subjectieve beleving van depressie

Karen Mutsaers

I7 Een pijnlijk levensverhaal: Het gebruik van levensverhalen in onderzoek en behandeling Ton Satink

Deel III Toepassingen in de praktijk

I8 Levensverhalen in de praktijk: Interventies in gezondheidszorg en welzijnswerk

Lausanne Mies

Het levensverhaal als onthuller van het levensthema:

Een Jungiaanse toepassing 283

Thomas Kok

Intermezzo: Spelenderwijs in gesprek 
20 Het meerstemmige verhaal: Grondslag voor een narratieve psychotherapie

Hubert J.M. Hermans en Gerben Westerhof

2I Herinner je toekomst: Levensverhaalmethoden in de ambulante geestelijke gezondheidszorg

Ernst Bohlmeijer, Frank Kempen en Leo Goetstouwers

Intermezzo: Een levensboek voor kinderen uit de jeugdzorg

Fiet van Beek

22 'Verklaar dat eens nader'

Gabriël Prinsenberg

23 Levensverhalen schrijven met ouderen

Eveline van de Putte

Intermezzo: Tao

Frank van Hartingsveld

24 Onderweg ontdek ik stukjes waarheid: Motieven voor en betekenis van het schrijven van het eigen

levensverhaal

José Franssen

$25 \quad$ Het bindend effect van reminiscentie

Pollo Hamburger

Intermezzo: Mijn leven? Ik kan er een boek over maken! Levensboeken in het kader van

belevingsgerichte zorg

José Franssen

26 Verbonden door verhalen: Het gemeenschappelijk belang van persoonlijke verhalen

Christina Mercken

27 Werken met levensboeken in de praktijk van de ouderenzorg

Wout Huizing en Thijs Tromp 
Intermezzo: De Verhalentafel

Sam Nemed

28 Levensverhalen en zorg voor mensen met een verstandelijke beperking

Herman P. Meininger

29 Narratieve coaching: Woorden om te worden

Jan Swagerman

Intermezzo: Luisteren in je leunstoel: Voorlezen aan ouderen

José Franssen

Bijlage

Personalia 


\title{
Introductie
}

\author{
'De enige manier om de wereld te begrijpen', zei Magnus, 'is door een \\ verhaal te vertellen. De wetenschap brengt kennis van de werking der \\ dingen. Verhalen brengen begrip.' \\ In: Marcel Möring, In Babylon
}

\section{Ernst Bohlmeijer, Lausanne Mies en Gerben Westerhof}

\section{Doelstelling}

Wat is de relatie tussen herinneringen en gezondheid?

Waarom roept Maria, een vrouw met een matige verstandelijke beperking, elke keer als het begint te regenen: 'Kijk, prima weer!'? En wat doe je dan als zorgverlener?

Welke betekenis kennen tien verschillende auteurs toe aan hun chronische depressie in hun levensverhaal?

Wat hebben levensverhalen aan onderzoekers te bieden?

Waarom verdienen levensverhaalmethoden een plaats in de gezondheidszorg?

Dit zijn voorbeelden van de vele vragen die in dit boek aan de orde komen. Het zal slechts weinigen ontgaan dat levensverhalen zich in een toenemende maatschappelijke belangstelling mogen verheugen. Autobiografische archieven, boekjes met vragen die je aan je grootmoeder of grootvader kunt stellen, televisieprogramma's met wonderbaarlijke levensverhalen, stambomen, terugkijken op je leven als therapie, het maken van levensboeken met dementerenden, dagboeken en weblogs... wat hebben levensverhalen en herinneringen ons in deze tijd te bieden? Is het een romantische hang naar een tijd waarin het vertellen van (levens)verhalen het grootste vermaak was? Zijn we in de persoonlijke geschiedenis van onszelf en onze voorouders op zoek naar identiteit, naar het antwoord op de vraag wie we zijn? Zijn we die identiteit dan kwijt? Of liggen in onze herinneringen misschien een (narratieve) waarheid en zin van ons bestaan verborgen die we willen achterhalen, reconstrueren? Vanwaar deze behoefte om 'op verhaal te komen?'. Laten we het u maar meteen zeggen: het definitieve antwoord op deze vragen wordt in dit boek niet gegeven. Er zijn theorieën en die komen aan bod. Levensverhalen en herinneringen, de bouwstenen van levensverhalen, hebben echter iets ongrijpbaars; 
hoeveel ontroering, melancholie, waardering, verbittering, waarheid en kracht ze ook meebrengen.

Ons tijdperk wordt wel gekenschetst als postmodern. Hadden we als moderne mensen nog houvast in het geloof in ons vermogen om de wereld naar onze hand te zetten, in vooruitgang en techniek, in rationalisme en een 'no-nonsensebenadering', in het postmoderne tijdperk is de twijfel toegeslagen. We zijn niet meer zo zeker van onze zaak. Terrorisme, milieurampen, nieuwe epidemieën, economische crises knagen aan de zekerheid van ons bestaan. Voor moderne mensen was religie een belangrijke bron van zingeving, zij bood houvast in bange dagen, voor de postmoderne mens is God à la Nietzsche 'doodverklaard'. We zijn geworpen in een wereld zonder a-priori betekenis. Onze reacties op deze leefomstandigheden zijn zeer divers. De één bejubelt de individuele vrijheid en zoekt het antwoord in een zeer persoonlijke spiritualiteit, de ander stort zich met extra inzet op tradities en orthodox geloof. Hoe dan ook, meer dan ooit lijken onze persoonlijke levenservaringen van belang bij betekenisgeving. Dit doet ons speculeren over de vraag of reminiscentie (het proces van herinneren van die ervaringen), vertellen en het reconstrueren van levensverhalen een functie kunnen hebben die eerder vooral werd aangereikt door mythen en geloofstradities: een persoonlijke speurtocht naar de betekenis en zin van ons bestaan. McAdams (1993) beschrijft hoe het levensverhaal dat we creëren kan fungeren als een persoonlijke mythe (zie de bijdragen van Bohlmeijer en van Hermans en Westerhof). Randall (2002) (zie ook zijn bijdrage in dit boek) beschrijft reminiscentie als het leren lezen van ons leven en trekt een parallel tussen reminiscentie en het lezen van romans. Hillman (1997), in navolging van Jung, laat zien hoe autobiografisch werk ons op het spoor van de ziel kan zetten (zie de bijdrage van Thomas Kok). De maatschappelijke betekenis van levensverhalen mag misschien giswerk zijn, wij (de redactie) zijn overtuigd van de betekenis van levensverhalen voor onderzoek in de menswetenschappen en de dagelijkse praktijk van gezondheidszorg en welzijnswerk; en ook van de mogelijkheid om deze betekenis haarfijn uit te leggen. Daarom hebben we dit boek tot stand willen brengen: om een multidisciplinair overzicht te bieden van deze betekenis voor onderzoek en zorgpraktijk. Daartoe hebben wij mensen uit wetenschap en praktijk benaderd met de vraag of zij vanuit hun specifieke kennis en ervaring een toelichting wilden geven op de betekenis van herinneringen en levensverhalen. Daarbij willen we direct twee kanttekeningen plaatsen. De eerste is dat dit geen handboek is. In dit boek staat niet beschreven 
hoe $\mathrm{u}$ levensverhalen in onderzoek kunt gebruiken en hoe u een bepaalde levensverhaalmethode kunt toepassen. Daarvoor verwijzen we naar de verschillende (werk)boeken die inmiddels zijn verschenen. De tweede kanttekening is dat we zeker niet geprobeerd hebben uitputtend te zijn. Levensverhalen en herinneringen hebben zoveel thematische raakvlakken, invalshoeken en toepassingen dat ons dit een onmogelijke taak leek. Wel verwachten wij interdisciplinaire inzichten gebundeld te hebben tot een boek dat een goede stand van zaken geeft met betrekking tot kennis over levensverhalen en levensverhaalmethoden.

Een specifiek doel is onderzoekers, managers en zorgverleners (in opleiding) inzicht te geven in de verschillende mogelijkheden die levensverhalen bieden en daarmee bij te dragen aan de implementatie van levensverhaalmethoden in de gezondheidszorg en het welzijnswerk. Want... het gezonde verstand doet ons beseffen dat een gezondheidszorg zonder aandacht voor levensverhalen ethisch niet verantwoord is, zoals Meininger in zijn bijdrage in dit boek verwoordt. Een gezondheidszorg zonder aandacht voor levensverhalen en zingevingsvragen (die misschien niet protocollair te beantwoorden zijn) is een kille bedoening waardoor veel mensen zich niet herkend en erkend zullen voelen.

\section{Opzet van het boek}

Het boek bestaat uit drie delen: I Theoretische beschouwingen, II Toepassingen in onderzoek en III Toepassingen in praktijk. Elk deel begint met één of meerdere hoofdstukken die een introductie geven op het onderwerp.

Het eerste deel begint met een verkenning van de relatie tussen herinneringen, levensverhalen en gezondheid door Ernst Bohlmeijer. Deze relatie wordt zowel beschouwd vanuit visies op ontwikkelingen in onze samenleving als vanuit de noodzaak om in diverse fasen van ons leven een nieuw verhaal over dit leven te creëren. Herinneringen leveren daarvoor de bouwstenen. Vervolgens gaat ontwikkelingspsycholoog Gerard Brugman dieper in op de kenmerken van levensverhalen in het tweede hoofdstuk. Een levensverhaal is in de eerste plaats een constructie: een theorie over het zelf, opgebouwd uit interpretaties van ervaringen uit het verleden, de eigen rol daarin en plannen voor de toekomst. In hoofdstuk 3 beantwoordt gerontoloog William Randall de vraag wat het betekent wanneer het verhaal als centrale metafoor wordt genomen voor een beter begrip van het ouder worden van de mens. Hij belicht dit thema vanuit vier dimensies: de persoon- 
lijke, de poëtische, de politieke en de professionele. Dit hoofdstuk werd eerder gepubliceerd in de Verenigde Staten en is met permissie van de uitgever vertaald in het Nederlands. In een boek over levensverhalen mag een bijdrage over het autobiografisch geheugen niet ontbreken. Psychologe Ineke Wessel geeft in hoofdstuk 4 een helder overzicht van de huidige wetenschappelijke kennis van dit complexe en mysterieuze systeem. Verschillende theorieën over de ontwikkeling, de werking en functies van het autobiografisch geheugen komen aan de orde. Bij de totstandkoming van levensverhalen spelen luisteraars en (denkbeeldig) publiek een belangrijke rol. In een filosofischreligieuze bijdrage legt Johan Bouwer een relatie tussen levensverhalen en troost in hoofdstuk 5. Deze relatie wordt besproken binnen de context van de zorg voor mensen met kanker en de rol van geestelijk verzorgers. In de laatste hoofdstukken van deel I komt de relatie tussen levensverhalen en cultuur aan de orde. In hoofdstuk 6 laat Marcus van Loopik zien welke rol levensverhalen in de joodse traditie spelen. De Thora staat vol met levensverhalen, maar tegelijkertijd overstijgen deze verhalen het persoonlijke. Levensverhalen zijn ideale bronnen van wijsheden die voor de overlevering en samenleving van belang zijn. Tot slot gaat filosofe Angela Roothaan in hoofdstuk 7 nader in op de relatie tussen cultuur en identiteit die in levensverhalen tot uitdrukking komt. Zij onderscheidt politieke, ideologische en affectieve aspecten. Dit illustreert zij aan de hand van het levensverhaal van de Nigeriaanse activist Ken Saro Wiws. Daarmee is in deel I een basis gelegd voor de betekenis van levensverhalen, uitgaande van het individu en diens herinneringen, de directe sociale omgeving waarin deze verkeert en de bredere culturele context.

In deel II geven wetenschappers van diverse pluimage een uitleg van de betekenis van levensverhalen in wetenschappelijk onderzoek. In de afgelopen jaren hebben levensverhalen, zij het soms schoorvoetend, als onderwerp van onderzoek hun weg gevonden in de wetenschap. In hoofdstuk 8 geeft de socioloog Gerhard Nijhof een introductie op het gebruik van levensverhalen als onderzoeksinstrument. Hij laat zien hoe levensverhalen actuele en door de cultuur geïnspireerde interpretaties van het verleden zijn. Daarnaast bespreekt hij wat het gebruik van levensverhalen toevoegt aan meer traditioneel kwantitatief sociologisch onderzoek. Ook gaat hij in op het probleem van de interpretatie van levensverhalen. Het genereren van levensverhalen en het analyseren ervan zijn twee aspecten van de methode die als uitgangspunt genomen werd voor de verdere indeling van deel II. De historica Arianne Baggerman bespreekt in hoofdstuk 9 de geschiedenis van de autobiografie. Met name de snelle maatschappelijke veran- 
deringen vanaf het midden van de negentiende eeuw blijken een reden te zijn om levensverhalen te gaan schrijven. Dat gesproken levensverhalen een andere dynamiek hebben dan geschreven levensverhalen komt in hoofdstuk Io aan bod. Hierin bespreekt historica Selma Leydesdorff aan de hand van een hernieuwd interview met een joodse vrouw die de holocaust overleefde, welke dynamiek er aan gesproken levensverhalen ten grondslag ligt. Inhoudelijk laat zij zien dat de analyse van levensverhalen haar op het spoor brengt van een 'antropologie van het overleven': hoe weten mensen zich in extreme omstandigheden overeind te houden? Vervolgens gaat antropologe Geeske Hoogenboezem in hoofdstuk II in op de vraag of het eigenlijk wel mogelijk is om als 'meisje uit de middenklasse' gedegen onderzoek te doen onder dak- en thuislozen. Zij laat zien op welke manieren machtsrelaties in het interviewproces doorwerken. Antropologe Els van Dongen laat in hoofdstuk I2 zien dat levensverhalen zich ook altijd afspelen in een sociaal-culturele context. In haar bijdrage gaat het om levensverhalen van ouderen na de afschaffing van de apartheid in Zuid-Afrika. Zij betoogt dat het vertellen van levensverhalen ook een zeer pijnlijk sociaal proces kan zijn. Na deze bijdragen, die zich inhoudelijk meer richten op het vertellen van levensverhalen, bespreekt filosoof Hans-Jan Kuipers in hoofdstuk $\mathrm{I}_{3}$ het proces van interpretatie van levensverhalen. Aan de hand van twee filosofen, Dilthey en Gadamer, laat hij zien dat de interpretatie zich enerzijds meer kan richten op de intenties van de verhalenverteller, anderzijds op de receptie door de luisteraar. Daarna volgen nog vier hoofdstukken, waarin verschillende manieren van interpreteren van levensverhalen aan bod komen. De psychologen Van Kordelaar en Westerhof hebben een thematische analyse gemaakt van de manier waarop ouderen betekenis geven aan het proces van pensionering in een snel veranderende maatschappij. Psychologe Anneke Sools maakte een thematische analyse van de betekenis van gezond leven bij oudere Marokkaanse immigranten, maar gaat in hoofdstuk 15 terug naar de gesproken levensverhalen, om te laten zien hoe onaf en gefragmenteerd dergelijke thema's daarin terugkomen. Psychologe Karen Mutsaers koos een andere interpretatiestrategie in haar bijdrage over levensverhalen van mensen met een chronische depressie. Zij onderzocht met name de verhaallijn, of de plot, van de levensverhalen. Een soortgelijke analyse van verhaallijnen, met opvallend genoeg soortgelijke conclusies, vinden we terug in hoofdstuk 17 . Hierin onderzoekt ergotherapeut Ton Satink levensverhalen van mensen met chronische lage rugpijn. 
Verschillende onderzoekers wijzen op grond van hun onderzoeksbevindingen op het potentieel voor het gebruik van levensverhalen in de (geestelijke) gezondheidszorg. In deel III worden verschillende van dergelijke toepassingen gepresenteerd. Hoewel de meeste toepassingen van levensverhaalmethoden plaatshebben in de gezondheidszorg en het welzijnswerk voor ouderen, worden ook toepassingen in jeugdzorg, de zorg voor mensen met een verstandelijke beperking, chronisch zieken en in loopbaanbegeleiding belicht. Lausanne Mies geeft in hoofdstuk I8 een overzicht van diverse soorten levensverhaalmethoden. Ze beschrijft door welke disciplines, met welke doelstellingen diverse methoden worden toegepast en gaat in op het belang de brede mogelijkheden voor toepassing te bevorderen. In hoofdstuk Ig beschrijft Thomas Kok in het kader van jungiaanse therapie, hoe men door verhalen het eigen levensthema onthult, zichzelf ontdekt. Hij beschouwt dit als het begin van een heelwordingsproces. De subjectiviteit van herinneringen en verhalen is wat elke therapeutische toepassing hoopvol maakt: we hebben invloed op ons verhaal; we kunnen het lot keren! Hermans en Westerhof gaan in hoofdstuk 20 in op de grondslagen voor narratieve psychotherapie. Dit hoofdstuk illustreert hoe de grondstructuur en thema's van het verhaal van de cliënt kunnen worden geëxploreerd en bewerkt. Het dialogische zelf, de dialogische relatie tussen de posities die de persoon inneemt, is onderdeel van therapie die kan leiden tot wijziging van bestaande structuren, posities en waarderingen. Vervolgens beschrijven Ernst Bohlmeijer, Frank Kempen en Leo Goetstouwers in hoofdstuk 2I twee specifieke interventies in de preventieve geestelijke gezondheidszorg: levensverhaalmethoden ter voorkoming van depressie bij (allochtone) ouderen. De resultaten zijn beloftevol. De hieropvolgende hoofdstukken illustreren hoe biografisch werken praktisch vorm kan krijgen. In het hoofdstuk van Prinsenberg komen de vaardigheden van de biografisch werker aan de orde. Beschreven wordt hoe begeleiders en therapeuten verhalende interesse kunnen tonen, welke technieken en houding zij kunnen of zouden moeten hanteren bij het ontlokken van verhalen en hoe zij deze verhalen kunnen interpreteren. Eveline van de Putte beschrijft vanuit haar ervaringen als docent creatief schrijven in hoofdstuk 23 de praktische en creatieve mogelijkheden van autobiografisch schrijven met ouderen. Voorbeelden van de onderwerpen, de keuzes die je hierin maakt en de vorm waarin men schrijft komen aan bod. Hoofdstuk 24 van José Franssen gaat eveneens over autobiografisch schrijven met ouderen. Zij laat in haar bijdrage de ouderen aan het woord. Het hoofdstuk geeft vooral inzicht in de motieven van ouderen om deel te nemen aan een schrijf- 
groep. Aan de hand van roerende citaten wordt duidelijk wat de beleving is van individuele ouderen, wat het hen oplevert om over het eigen leven te schrijven. De verbindende kracht van verhalen wordt verder uitgelicht in de bijdragen van Pollo Hamburger en Christina Mercken. Het reminiscentiewerk dat Pollo Hamburger in het Flevohuis beoefent, is niet alleen van waarde voor de individuele oudere die zich door het ophalen van herinneringen en de terugblik op prettige levenservaringen veelal completer en harmonieuzer voelt. Reminiscentie is ook van betekenis voor contacten met verzorgers, met buurtbewoners - leeftijdsgenoten, mensen van jongere generaties en van verschillende culturele afkomst - en het contact tussen mantelzorger en dementerende oudere. De Geheugen van... projecten waarover Christina Mercken schrijft, illustreren hoe individuele verhalen een collectief belang kunnen dienen. Het online verzamelen van allerlei verhalen van bewoners in een buurt, wordt hier als middel gezien om de verbondenheid in de gemeenschap te versterken: een community benadering die met het oog op integratie voor vele gemeenten interessant kan zijn. Contact, verbinding, elkaar kennen; het zijn duidelijk behoeften waaraan de narratieve benadering kan beantwoorden. Tromp en Huizing zijn op zoek naar evidence, naar effecten van het werken met levensboeken in de ouderenzorg. In hoofdstuk 27 beschrijven zij de manier waarop deze effecten van de door hen ontwikkelde methode Open Kaart zowel voor de ouderen als voor de zorgverleners worden onderzocht. De implicaties voor de zorgpraktijk komen eveneens aan bod. Meininger, ethicus en adviseur van een zorggroep voor mensen met een verstandelijke beperking, benadrukt in hoofdstuk 28 de morele en praktische relevantie van het werken met levensverhalen in deze sector en breder: levensverhalen zijn een gids voor waarachtige ontmoetingen met de ander. Tot slot geeft Jan Swagerman een impressie van narratieve coaching. Hij beschrijft de uitgangspunten en methoden om mensen in werksituaties te begeleiden, zowel in de profit- als in de non-profitsector, en licht deze met enkele voorbeelden toe.

Als opwarmer start het boek met een literaire visie op autobiografische herinneringen van de schrijver Marcel Möring. In het boek treft u verder een aantal intermezzo's. Dit zijn korte stukjes waarin boeken, toepassingen en beschouwingen worden beschreven die geen plaats vonden in de hoofdstukken, maar die in onze ogen wel een 'spotlight' verdienden. 
Tot slot willen we de auteurs die een bijdrage hebben geleverd aan dit boek heel hartelijk danken voor hun moeite en enthousiasme; zij hebben het boek gemaakt tot wat het is. We willen ZonMw danken voor de visie en financiële steun die de realisatie van dit boek mogelijk maakten. Als redactie stond ons vooral een boek voor ogen met een wetenschappelijke grondslag dat prettig leest en inspireert. We hopen van harte dat we daarin zijn geslaagd. Het woord is aan $\mathrm{u}$, de lezer.

\section{Literatuur}

Hillman, J. (1997). De code van de ziel. Amsterdam: Uitgeverij Bert Bakker. McAdams, D. (1993). The stories we live by. New York: The Guilford Press. Randall, W. (2002). Reminiscence as reading our lives. In: J. Webster \& B. Haight, Critical advances in reminiscence work. New York: Springer Publishing Company. 


\section{Marcel Möring}

In den beginne was er... de bijbel. Of beter: Het Oude Testament. Ik herinner mij hoe mijn vader op een avond thuiskwam met een in goedkoop bruin papier gewikkeld pakje onder zijn arm en dat aan mij gaf. Toen ik het voorzichtig had uitgepakt, bleek het een in rood linnen gebonden boek te zijn. 'Een bijbel,' zei mijn vader. 's Avonds in bed las ik strips, Donald Ducks vrolijke weekblad, en de boeken die mijn vader als jongen had gelezen. Ik deed dat bij het licht van een kleine zaklantaarn waaraan een magneetje zat, zodat ik hem tegen de metalen onderzijde van het bed kon klikken als mijn moeder kwam kijken of ik wel sliep. Ik was al een lezer, ik kon lezen voor ik naar school ging, maar tot nu toe had ik nog nooit de totale onderdompeling meegemaakt, de leeservaring die zo overweldigend is dat je de wereld van het boek met tegenzin verlaat.

Die nacht begon ik in het Oude Testament en toen ik ophield had ik Genesis uit. De volgende dag ging ik in een soort waas naar school. Dat kwam niet alleen omdat ik de halve nacht had liggen lezen, maar ook omdat een deel van mij nog steeds daar was, in de wereld van het boek. Het andere deel, dat naar school wandelde en achter het tafeltje zat en naar de onderwijzer luisterde, verlangde naar de komende nacht, als ik weer zou kunnen lezen.

Het kostte mij ongeveer twee maanden om het boek helemaal uit te lezen en toen ik dat had gedaan, begon ik opnieuw. Gedurende de volgende twee, drie jaar las en herlas ik die bijbel. Elke nacht knipte ik mijn zaklantaarntje aan, richtte het op de verweerde pagina's en betrad het boek. Ik hoorde de mensen in mijn boek spreken. Ik kon ze zien. Ik wandelde met ze. Ik at met hen. Ik deelde hun angsten. Het was geen lezen meer. Ik leefde, letterlijk, in hun lang vervlogen verre wereld. Zelfs vandaag nog, meer dan dertig jaar later, is het beeld dat ik van Abraham heb kristalhelder en ik hoef mijn ogen maar te sluiten om de drie vreemde gasten te zien verschijnen, hun silhouetten wazig in de schelle woestijnzon. Ik sprak zelfs met God, niet in overdrachtelijke zin, maar in duidelijke, klinkende taal. Ik zag 
hem, destijds, als een wat tobberige figuur die een gesprek met een jongetje als ik wel op prijs stelde.

Zet een paar mensen om het vuur - het makt niet uit of het mannen, vrouwen, jongeren of kinderen zijn - en het moet wel gek zijn als ze elkaar na verloop van tijd geen verhaal vertellen. Bloemen mogen dan van mensen houden, mensen houden zelf vooral van verhalen. Het meeste houden ze nog van sprookjes. Het is waarschijnlijk het begin van onze literatuur geweest: die paar mensen bij elkaar, even vrij van de strijd om eerste levensbehoeften en daardoor juist weer in het volle besef van het gewicht van het leven.

Het maakt niet uit of men tevreden is als men vertelt, of juist hongerig, moe of dorstig. In het eerste geval zal het verhaal gaan over de dingen waar we, beschut en gevoed en gelaafd, bang voor zijn. In het tweede geval fantaseren we over tafels die doorbuigen onder het gewicht van de dampende schalen, met van vet glanzende gerechten en huizen waar het altijd warm en droog is. Daarom verzinnen Amerikaanse teenagers griezelverhalen rond hun kampvuur (omdat hun angsten niet meer om primaire levensbehoeften draaien) en bedachten Hezbollah-gijzelaars en concentratiekampgevangenen arcadische vertelsels van overvloed en warmte en geluk. Je kunt zeggen dat het verhaal dat we bedenken altijd gaat over hoe het niet met ons gaat en daardoor juist over hoe het eigenlijk met ons gaat.

Sprookjes verschillen vooral van andere verhalen, omdat ze een gebied bereiken waar rede niet meer geldt en logica zinloos lijkt. Het is het gebied waar je niet meer weet, maar voelt. En net als andere heel oude dingen zijn ze soms moeilijk te lezen. Als de argeloze wandelaar een kei vindt, is dat misschien een mooie steen. Voor een archeoloog is het een mislukte vuistbijl die door een chagrijnige steentijdjager is weggegooid. Met sprookjes is het precies hetzelfde. Als Freud en Jung iets goed hebben gezien, dan is het wel dat de mythe en het sprookje meer zijn dan ze zijn en een verhaal vertellen dat ze niet lijken te vertellen. Elk sprookje kan worden gelezen, zoals een schilderij iconografisch wordt geanalyseerd: Kijk, deze in lompen gehulde figuur die met zijn knapzak op weg gaat, dat is de verloren zoon. Het is een ingewikkelde manier om iets te lezen wat eenvoudig is bedoeld, maar het werkt wel.

Laat ik $u$ een herinnering vertellen. Ik ben een jaar of zeven en met mijn moeder loop ik over een hoge, dichtbegroeide spoordijk. We wandelen onder de bomen. Af en toe komt er een auto voorbij over de weg die helemaal van het station naar de haven loopt. Daar, aan de 
haven, op de dijk die tussen de laadterreinen en de spoordijk ligt, wonen mijn grootouders in een enorm huis met een diepe tuin. Er staat een walnotenboom in die tuin en een pruimenboom en achter de schuur blinken onder de hoge zon de ruiten van de kas waarin mijn grootvader planten teelt. Maar wij gaan niet naar de IJsbaanweg. Voor we de splitsing bereiken, steken we de straat over. We staan voor een winkel. Het is een hoekpand. We gaan niet door de deur. Mijn moeder loopt langs de zijmuur en opent een groene houten poort en we stappen een zonovergoten binnenplaatsje op. Daar, te midden van de oprijzende stenen wanden, in bebloed voorschoot, een lang mes in zijn hand, staat slager Samson.

Ik heb deze herinnering gebruikt in een nooit-gebruikt hoofdstuk voor mijn eerste roman, Mendels erfenis. Dit is het stukje waarover ik het wil hebben:

De winkel was leeg. Hij sloeg de deur hard achter zich dicht. Er kwam niemand. Hij riep 'hallo' en 'volk' en toen na enig wachten nog niemand kwam, passeerde hij de toonbank en ging hij het donkere gat in van de deur die naar achteren leidde.

Hij kwam in een kille, stenen ruimte, met een vloer van gladgestreken cement en wanden die met glanzende olieverf waren bestreken. Tegen de wanden waren planken geschroefd waarop gereedschappen stonden die glansden in het schaarse licht. Aan de andere kant van de ruimte kierde een streep daglicht onder een deur. Achter de deur klonk het geklos van zware rubberen laarzen en een geluid dat hij niet kon thuisbrengen. Hij opende de deur en keek op de binnenplaats achter de slagerij. Samson stond met zijn rug naar hem toe en maakte korte, rustige bewegingen met zijn rechterarm. De cementen vloer van de binnenplaats werd begrensd door een brede, ondiepe goot, om de plaats stonden muren en huizen, aan de overkant was een groengeverfde houten schuur. Tegen de schuur stond een korte, verveloze ladder.

Samson beëindigde het bewegen van zijn arm en stapte opzij. Hij keek om de deur. De slager legde een wetstaaf en een lang, gepunt mes op een donker hakblok, waarin gevlamde sporen van oud bloed zichtbaar waren. Op het blok lag een blinkend witte marmeren plaat. Hij opende zijn mond om de slager aan te spreken, maar zijn keel liep vol met voorgenomen woorden en bracht niets voort. De slager stak de plaats over en ging de schuur binnen. Een melancholiek, gedempt briesen klonk. Hij kwam achteruitlopend naar buiten. Aan een rafelig halster van touw leidde hij een okerkleurig 
paard. Het paard stapte tastend op het cement van de binnenplaats en keek in het rond.

'Hans. Hans!'

Achter zich hoorde hij het gestommel van iemand die een trap af rent. De deur aan de andere kant van het hok ging open en uit het licht van de winkel kwam een jongen van zijn leeftijd binnen, op kousenvoeten. Hij keek hem peinzend aan. Hij liep naar de planken langs de muur, trok er een paar laarzen af en liep met de laarzen in zijn hand, langs hem, de binnenplaats op. Samson gaf de jongen het halster en klopte het paard met vlakke hand op de hals. Terwijl de jongen het halster vasthield en tegelijkertijd zijn laarzen aantrok, liep Samson naar het hakblok waarop hij zijn mes en wetstaaf had gelegd. De slager pakte het mes, hield het omhoog en keek naar de snede. Hij liet zijn nagel langzaam langs het scherp gaan. Toen draaide hij zich om en liep naar het paard. Hij slikte. Zijn buik stroomde vol met natte warmte. Hij wilde weg. De jongen bij het paard had zijn laarzen nu aan. Hij streelde zacht de hals van het paard, dat zijn hoofd tegen de borst van zijn begeleider had gelegd. De gehaaste jongen van net, die op kousenvoeten liep en met één hand een paard vasthield en, hinkend en hompelend, met zijn andere hand zijn laarzen probeerde aan te trekken, had iets plechtigs gekregen. Hij trok het halster naar beneden, het paard zakte op de knieën en rolde traag op zijn zij. Samson liep om het dier, nam het halster over, trok het hoofd van het paard naar achteren en haalde met een vloeiende beweging het mes over de zijkant van de hals. Het paard schrok kort en schopte even op een merkwaardige luie manier met de benen, alsof het plotseling bedacht dat het een veel te mooie dag was om drukte te maken om zoiets futiels als sterven. Toen verslapte het grote lichaam en strekte het dier zich uit op de gladde cementen vloer.

Terwijl hij had staan kijken naar de onafwendbare halssnede, was de vrees voor de dood en het bloed in hem gegroeid. Nu het gebeurde, nu het bloed er was en hij de schaduw van de dood over het grote dier zag glijden, nu was er niets. Wat hij had gevreesd als een groot en duister ritueel, had zich ontladen in een haast achteloze handeling. Het dier, dat met zoveel vertrouwen het hoofd aan de borst van de slagersjongen legde, was niet de dood in gelokt, het had zijn leven in handen gegeven van een zachte, vriendelijke god. Het paard lag uitgestrekt op het plaatsje. Bloed stroomde traag uit de geopende halsslagader en vormde een uitvloeiende, donkere plas die uitmondde in een dun stroompje dat langzaam kronkelend zijn weg zocht naar de goot. Het leven was uit het lichaam verdwenen, 
de ogen waren leeg, de okeren huid was slap, de vochtige donkere lippen waren droog.

'En?'

Voor hem stond Samson. Het voorschoot van witte, glanzende oliestof was bespat met een waas van kleine rode druppeltjes. Het mes, bedekt met een dunne film van vers bloed, hing losjes in de rechterhand.

Dit deel van het nooit-gebruikte hoofdstuk voor Mendels erfenis baseerde ik op mijn eigen herinnering aan slager Samson, de Enschedese koshere slager die beroemd was in de hele mediene, zoals joden de provincie noemen. Ik heb slager Samson, voor zover ik weet, nooit gesproken. Ik herinner mij dat mijn moeder en ik op zijn binnenplaatsje stonden, maar ik weet niet of slager Samson ooit wel een binnenplaatsje heeft gehad. En, nu we toch bezig zijn, zou hij een paard hebben geslacht? Het lijkt mij sterk: paarden zijn niet kosher. En toch, die herinnering staat mij zo helder voor de geest, dat het is alsof mijn latere twijfel onwaarschijnlijker is dan de bedrieglijke herinnering zelf. Nog iets anders: dat enorme huis van mijn grootouders, dat op die kolos van een dijk aan de Twenthe-Rijn-haven lag, bleek toen ik er een paar jaar geleden op verzoek van een journalist ging kijken, helemaal niet zo groot. De kas was stukken kleiner dan ik mij herinnerde en de IJsbaanweg, die doodstille klinkerstraat onder lommerrijk groen bleek een slecht onderhouden, doodlopend weggetje met zieltogende eenmansbedrijfjes.

De herinnering is een hoer. Zij geeft zich af met wie zin in haar heeft en plooit zich zonder aarzeling naar de wensen van haar minnaars. Een van de kenmerken van de herinnering is dat zij begint waar het ons uitkomt, vooral de collectieve herinnering. Die van de Duitsers begint waar Bismarck de vorstendommetjes bijeenveegt en de Duitse natie definieert. Die van Kroaten waar Kroatië nog iets voorstelde, die van de joden waar er zoiets als een joodse staat leek te bestaan, die van de Palestijnen waar zoiets als een joodse staat niet leek te bestaan. Niets verraderlijker dan de herinnering, niets zoetgevooisder, niets warmer en sussender. En tegelijkertijd: niets angstaanjagender dan de herinnering die niet wil wijken, die 's nachts als een gevreesde oude bekende opstaat uit zijn graf en begint te spreken.

Wie over de herinnering praat, dient dat te doen als een man die horden loopt met een fles nitroglycerine in zijn zak.

Ondanks alles is het die bedrieglijke, verblindende herinnering die ons meer dan al het andere bepaalt. Wij zijn niet wat wij zijn geworden. Wij zijn niet wat wij verwierven. Wij zijn wat we waren en waar 
we waren. Het is niet de weg die we op zullen gaan die ons maakt tot de mensen die we zijn. Het is de weg die we gingen.

Wat was ik toen ik onder de walnotenboom van mijn grootouders alle tegels op de binnenplaats volkalkte met de letters NP? Wat was ik toen ik elke dag van het huis van mijn grootouders naar dat van Elvira liep, aan het einde van de IJsbaanweg, om daar met haar in het bos Winnetou en Old Shatterhand te spelen, of in haar vaders atelier de kleibak te openen en poppetjes te boetseren, of van de betonnen vloer de vlekjes kopersmeltsel op te rapen die wij 'sterretjes' noemden? Een jongetje van nog geen tien jaar. Een jongetje dat archeoloog wilde worden. Ik was nu en straks. Ik had geen idee van gisteren, vorige maand, vorig jaar. Terwijl ik nu, veertig jaar later, merk dat ik steeds meer het straks afmeet aan het toen. Naarmate ik mij verder van het toen verwijder, wordt de rol die het speelt groter.

De herinnering maakt het ons mogelijk een groot huis te zien waar het klein was en een dood paard op een binnenplaatsje waar waarschijnlijk geen binnenplaatsje, laat staan een paard, was. Maar het is nooit mogelijk om de herinnering aan wat we waren en waar we vandaan kwamen te vergeten. Ook de anderen vergeten dat nooit. Op een ochtend in de zomer van 1937 belde Ludwig Wittgenstein zijn toenmalige lerares Russisch, Fania Pascal. Hij wilde haar spreken. Omdat een van haar kinderen wat kwakkelde, vroeg Pascal of het erg dringend was, of het niet kon worden uitgesteld. Wittgenstein antwoordde, nogal dramatisch voor zijn doen: 'If ever a thing could wait'.

Hij kwam langs, gehaast, gespannen. Dergelijk gedrag van de anders zo beheerste Wittgenstein was zo opmerkelijk dat Pascal het beeld meer dan veertig jaar later nog voor zich zag: Wittgenstein streng rechtop in de stoel, de jas helemaal dichtgeknoopt, buitengewoon nerveus.

'Ik ben gekomen om iets op te biechten', zei Wittgenstein, en hij vertelde dat hij eerder al bij professor Moore was geweest om daar hetzelfde te doen.

'Wat zei Moore?' vroeg Pascal.

'Hij zei: "Wittgenstein, je bent een erg ongeduldig mens." 'En,' zei Pascal, 'wist je nog niet dat je dat was?'

'Nee, dat wist ik niet.'

Daarna begon de biecht. Wittgenstein bekende twee 'misdaden': dat hij van joodse komaf was en dat hij ooit een leerlingetje een klap had gegeven toen hij dorpsonderwijzer was in Oostenrijk. 
Over dat eerste zei hij dat de meeste mensen die hem kenden, dachten dat hij driekwart 'Arisch' was en een kwart joods. Maar eigenlijk, bekende Wittgenstein, was het andersom en had hij nooit iets ondernomen om dat misverstand uit de weg te ruimen.

'Ik ben joods,' antwoordde Pascal, 'en ik heb vaak de kans voorbij laten gaan om dat op tijd te vertellen, om anderen te stoppen als ze hun afkeer van joden openbaarden. Maar hoe dan ook, de Engelsen zijn sluw. Ik neem aan dat ze het van mij weten en waarschijnlijk ook van jou...' Wittgenstein keek hoopvol op, toen ze dat had gezegd. Fania Pascal noteerde haar herinneringen aan de Engels-Oostenrijkse filosoof zo rond I980, en toen vroeg ze zich nog steeds af waarom Wittgenstein ineens had gevonden dat hij moest opbiechten dat hij joods was, waarom toen en met zoveel haast. Pascals verklaring ligt in de tijd: I937, de groei van de nazistaat, het tijdperk waarin het langzamerhand ook buiten Duitsland een precaire aangelegenheid was om jood te zijn. Vond Wittgenstein dat hij niet langer schuil mocht gaan in een misverstand? vroeg zij zich af. Kon hij zich niet verbergen, nu duidelijk werd dat op het continent joden door de straten werden gejaagd? Pascal wist het niet en Wittgenstein heeft er nooit meer over gesproken.

Misschien wilde Wittgenstein ook wel duidelijk maken wie en wat hij was, omdat hij wist dat mensen elkaar pas echt kennen als zij elkaars verhaal weten. We voelen ons onzeker in een wereld waarin de mensen en de dingen niet zijn wat ze lijken. En omdat wij ons onzeker voelen maken wij van de wereld en de mensen een verhaal. Het doet er niet veel toe of het verhaal 'waar' is in de zin van verifieerbaar correct, of 'echt' in de zin dat dit verhaal iets over ons zegt. Wittgensteins schijnbaar onbeduidende verhaal, dat hij eigenlijk joods was en ooit een leerlingetje sloeg, is net zo waar en echt als mijn zeer waarschijnlijk niet-correcte herinnering aan een Enschedese koshere slager. Hij vond dat zijn verhaal iets wezenlijks over hem zei, ook al vond Fania Pascal dat in eerste instantie niet. Ik dacht dat mijn staaltje verdwenen jodendom uit de provincie iets duidelijk maakte over mij en mijn omgeving. Wij beiden vertelden hetzelfde: Kijk, dit is wie wij zijn, ik sta nu als een verhaal tegenover u. Onze verhalen zijn tegelijkertijd bekendmakingen en uitnodigingen om het verhaal van de ander te horen. Misschien worden wij samen een nieuw verhaal, of het vervolg van onze eigen verhalen. 